\title{
Indian Money and Equity Market: Are They Entwined?
}

\author{
Hirak Ray, Joy Sarkar, Debashree Dey \\ Department of Commerce, University of North Bengal, Dt. Darjeeling, Pin, India \\ Email:hrcnbu@gmail.com,joy_nbu@yahoo.com,deydebashreenbu@gmail.com
}

How to cite this paper: Ray, H., Sarkar, J., \& Dey, D. (2021). Indian Money and Equity Market: Are They Entwined? Modern Economy, 12, 516-533.

https://doi.org/10.4236/me.2021.123027

Received: January 6, 2021

Accepted: March 15, 2021

Published: March 18, 2021

Copyright $\odot 2021$ by author(s) and Scientific Research Publishing Inc. This work is licensed under the Creative Commons Attribution International License (CC BY 4.0).

http://creativecommons.org/licenses/by/4.0/ (c) (i) Open Access

\begin{abstract}
After almost three decades of the New Economic Policy of the Government of India, now it is high time to assess the policy prescriptions so far followed to converge the financial markets, especially the stock and money market, objectively with the robust statistical and econometric tools. This paper attempts to measure the integration amongst stock and some select segments of Indian money market. The results of Johansen and Juselius (1990) cointegration test suggest strong integration amongst the markets and statistically significant presence of all the markets in the cointegration space. Granger causality expectedly runs from money to stock market and Forecast Error Variance Decomposition Analysis indicates the rigidity of the stock and treasury bills market only, hence, warrants more attention of the Indian policy planners for adequate steps to make these markets more flexible.
\end{abstract}

\section{Keywords}

Stock Market, Money Market, Cointegration, Causality, Impulse Response Analysis, Forecast Error Variance Decomposition Analysis

\section{Introduction}

After the seminal work of White (1910), several scholars attempted to search and analyse the relation between stock and money market considering stock market as the "mirror" of the economy (Galbraith, 1955) and money market as the major channel to transmit monetary policy shocks to the economy. Money market, with its all segments, assumes a vital role in shaping investing decisions of economic units across the available options in the economy including the equity market. Money market rates, that is, short-term interest rates are virtually the "high frequency" reaction of the monetary policy. Investor's expectation about the course of monetary policy is widely reflected by the prices of the equity in- 
struments of the market. Moreover, expectation about the changes in shortterm interest rates also influences the expectation about the changes in the long-term interest rates, cost of borrowings, lendings, investor's behavior to select right option to invest, economic activities and output (Bernanke \& Kuttner, 2004; Ehrmann, Fratzscher, \& Rigobon, 2009). We strongly believe that the smooth transmission of the shocks from money to equity market would not be possible if the markets are not well integrated.

The objective of the paper is to examine and measure the 1) co-integration amongst the Indian equity and select money market segments; 2) if co-integrated then a) the efficiency, b) predictive causality and c) dynamic relation of the markets under the study and 3) ranking the money market segments on the basis of their statistical qualities to influence equity market in India over a period ranging from January, 2008 to July, 2018. The remainder of the study is structured as follows: Section 2 deals with, in brief, the earlier theoretical and empirical researches on the relation between the stock market and money market represented by select short-term interest rates. Data and time period are provided in Section 3. Empirical methodology, results and their interpretations are detailed in Section 4. Section 5 sums up the findings and concludes the study.

\section{Survey of Literature}

The link and linker(s) between stock market and money market are discussed and debated by the scholars discretely for more than a century (see White, 1910). Majority of the scholars agreed that equity prices certainly and strongly react to monetary policy impulses. It is widely argued and attested that an increase in short term interest rate raises the "discount value" and lowers the demand for goods and services resulting a decline in equity prices (Bernanke \& Kutner, 2004; Ehrmann, Fratzscherand, \& Rigobon, 2009). According to Tobin (1969), if the equity prices increases then economic units can raise more funds by issuing smaller number of shares which ultimately increases the investment and output and lowers the interest rates. Modigliani (1971) posited that a permanent increase in the security prices results in increase in the individual's wealth holdings leading to higher permanent income. Hence, on the occasions of rise in equity prices, consumers will be able to readjust upwards their consumption level which finally, influence demand and interest rates. Several scholars, in the line of Tobin (1969), observed and advocated that, if the price of equity shares increases then the companies can afford to offer more collaterals and lift more funds which mostly put an upward pressure on the demand for the funds. Hence, rise in the equity prices triggers an expansion of the economy and influences the interest rates conditional to the availability of funds (Bernanke \& Gertler, 1989; Kiyotaki \& Moore, 1997).

"Cost of risk free capital" is widely used as a benchmark tool in both the micro and macro-economic decision-making as the scholars believe that stock price represents discounted value of expected dividend. The highly acclaimed theory 
of "capital asset pricing model", also posits that any rise in risk free short term rate will result in a decline in asset price and vice versa (Wongbangpo \& Sharma, 2002; Clark \& Kozicki, 2005; Abdullah \& Hayworth, 1993; Ray, 2007). There are also some dissent views and puzzling empirical observations on this issue (AL-Sharkas, 2004; McMillan, 2001; Nasseh \& Strauss, 2000). Schwert (1989) investigated the relationship amongst stock prices and several other major macroeconomic variables including short term interest rates in United States over the period 1859 to 1986 . He found no close relation amongst the variables under his study. Furthermore, he observed that short term interest rates have strong relation with the "financial crises" than the changes in the stock prices. Ehrmann, Fratzscher and Rigobon (2009) investigated the issue over a period of about 16 years (1989 to 2004) and reported that in United States the short term interest rates react more by changes in the stock prices but have no impact in the "euro area". Wongbangpo and Sharma (2002) found a negative relation between interest rates and stock price in Philippines, Singapore and Thailand but positive relation in Indonesia and Malaysia.

Virtually, short term interest rate and its impact on asset prices are marred by endless debate without any objective answer. The advocates of Keynesian theory argue in favour of low interest to encourage more consumption and increase in demand in the economy. This increase in demand promotes investment and growth of the economy by influencing economic activities including the asset market. On the other hand, neo-liberalists reject Keynesian view and suggest that rise in real interest rate helps to accumulate more savings and create more funds which ultimately are available in the economy for investment, and hence, the equilibrium rate of investment and efficiency of firms will finally increase (Fry, 1978; Agarwal, 2004).

The relationship and the causal direction between the short-term interest rate and asset returns are theoretically and empirically investigated by several scholars considering different time periods, methodologies and economies but fail to give us any definite clue regarding the complex relationship that exists between money and stock markets (Wong et al., 2005; Acikalin et al., 2008; Khrawish et al., 2010; Pallegedara, 2012; Addo \& Sunzuoye, 2013). Moreover, the literature on this issue considering a big but developing economy like India is scanty. In an attempt to empirically evaluate the extent of integration amongst the Indian financial markets in the post-liberalisation period, Bhoi and Dhal (1998) found no causal link between capital market and money market and specifically no long term stable relation between capital and call money markets. Their paper examined the movement of monthly rates/returns covering 60 months from April 1993 to March 1998 only. Jena et al. (2004) empirically examined the impact of the policy and institutional reforms in India in narrowing down the inter market divergence by studying five markets including money and capital market. Using monthly data spanning from March 1993 to March 2002, their study found positive relation amongst call, treasury bills and stock market. However, on the basis 
of the results of both the correlation matrix and the cointegration test, they, further, noted that there seems to be no long-run relationship between the capital market and other short-term markets. Finally, the authors concluded that while the reform process had helped in removing institutional bottlenecks to flow capital freely across various segments of the financial markets in India, the event had not yet been translated into complete integration among them. A similar study by Sanati (2010) found contradictory results of correlation in the variables of stock market and yield on 91 days treasury bills. Ray and Sarkar (2014) investigated the dynamic relation between the stock market and the select macroeconomic variables at log-levels, in India, for the period 1991:01 to 2008:04. Findings of the study showed that the long-run stock market behavior is negatively related to short and long-term interests.

In sum, almost all the earlier studies reviewed under this paper used the monthly data and, in general, the estimations based on the monthly data provide only a short-run insight about the markets (Dimitrova, 2005). Furthermore, use of a variety of methodologies, partial empirical searching and fractured findings suggest that there are scopes for further research to unveil the intricate relationship between the money and stock market. Wide implications of the issue, especially in the treasury management, investment and related decisions of financial institutions, overall monitoring and management of the liquidity in the economy by the policy planners demand the debate be settled on the basis of objective investigation using more robust tools drawing from the literature of statistics and econometrics.

\section{Data and Time Period}

This paper humbly attempts to investigate the issue in the context of India considering the select segments of money market and stock market. For our empirical investigation, the data, at log-level, consist of 91-days Treasury Bills (TB), Certificate of Deposit (CD), Commercial Paper (CP), Call Rate (CR) and the BSE SENSEX 30 (SX) to represent money and stock market, respectively. We have used fortnightly data series for all the variables under this study from January, 2008 to July, 2018. The data are collected from the various official publications of the Reserve Bank of India, The Bombay Stock Exchange, etc.

\section{Empirical Methodology and the Findings}

\subsection{The Relationship}

To attest the objective of this study, firstly, we have examined the stationarity of each series by following the methodologies posited by Said and Dicky (1984) (ADF test), Elliott, Rothenberg and Stock (1996) (DF-GLS test) and Ng and Perron (2001), using primarily the lag order suggested by Schwarz Information Criteria (Schwarz, 1978), with "constant" and with "constant and time trend". We deliberately escaped the discussion on methodology for testing unit-root, as the basics are widely known and available in text books. The results of the tests 
are presented in Table $1(\mathrm{a})$, Table $1(\mathrm{~b})$ and Table $1(\mathrm{c})$, respectively.

It is observed that all the series are integrated of order one at one per cent level of significance when tested with "constant" and "constant and trend." save $\mathrm{CP}$ and $\mathrm{CR}$ which are significant at a little bit more than one percent level with "constant" only under both the DF-GLS and Ng-Perron tests. Following the earlier studies which experienced almost the similar results (see Al-Sharkas, 2004; Humpe \& McMillan, 2007; Ray, 2008) we proceed to our next stages of

Table 1. (a) ADF Test for Unit Root; (b) DF-GLS Test for Unit Root; (c) Ng-Perron Test for Unit Root.

(a)

\begin{tabular}{ccccccc}
\hline \multirow{2}{*}{ Variables } & \multicolumn{3}{c}{ With Constant } & \multicolumn{3}{c}{ With Constant and Trend } \\
\cline { 2 - 7 } & Lag Order & t-statistic & p-value & Lag Order & t-statistic & p-value \\
\hline LNSX & 1 & -0.558090 & 0.8760 & 1 & -3.352376 & 0.0604 \\
$\Delta$ LNSX & 0 & $-13.52974^{*}$ & 0.0000 & 0 & $-13.55193^{*}$ & 0.0000 \\
LNCD & 0 & -2.140186 & 0.2292 & 0 & -2.128569 & 0.5269 \\
$\Delta$ LNCD & 0 & $-19.98962^{*}$ & 0.0000 & 0 & $-19.94855^{*}$ & 0.0000 \\
LNCP & 6 & -2.300291 & 0.1727 & 6 & -2.326949 & 0.4174 \\
$\Delta$ LNCP & 5 & $-5.528649^{*}$ & 0.0000 & 5 & $-5.518630^{*}$ & 0.0000 \\
LNCR & 1 & -2.209872 & 0.2034 & 1 & -2.238404 & 0.4658 \\
$\Delta$ LNCR & 0 & $-25.17840^{*}$ & 0.0000 & 0 & $-25.12753^{*}$ & 0.0000 \\
LNTBL & 1 & -1.735778 & 0.4120 & 1 & -1.805087 & 0.6996 \\
$\Delta$ LNTBL & 0 & $-12.73168^{*}$ & 0.0000 & 0 & $-12.70629^{*}$ & 0.0000 \\
\hline
\end{tabular}

Note: 1) $\Delta$ Represents first difference of the respective variables. 2) ${ }^{\star}$ Indicates rejection of null hypothesis at one percent level of significance.

(b)

\begin{tabular}{|c|c|c|c|c|c|c|c|c|}
\hline \multirow{3}{*}{ Variables } & \multicolumn{4}{|c|}{ With Constant } & \multicolumn{4}{|c|}{ With Constant and Trend } \\
\hline & \multirow{2}{*}{$\begin{array}{c}\text { Lag } \\
\text { Order }\end{array}$} & \multirow{2}{*}{ t-statistic } & \multicolumn{2}{|c|}{ Critical Value } & \multirow{2}{*}{$\begin{array}{c}\text { Lag } \\
\text { Order }\end{array}$} & \multirow{2}{*}{ t-statistic } & \multicolumn{2}{|c|}{ Critical Value } \\
\hline & & & $1 \%$ Level & $5 \%$ Level & & & $1 \%$ Level & $5 \%$ Level \\
\hline LNSX & 1 & -0.536000 & -2.574171 & -1.942089 & 1 & -1.486066 & -3.465200 & -2.919600 \\
\hline$\Delta$ LNSX & 1 & $-2.331804^{* \star}$ & -2.574208 & -1.942094 & 1 & $-4.684712^{\star}$ & -3.465100 & -2.919800 \\
\hline LNCD & 1 & -1.720163 & -2.574171 & -1.942089 & 1 & -1.720236 & -3.465200 & -2.919600 \\
\hline$\triangle \mathrm{LNCD}$ & 1 & $-3.599346^{*}$ & -2.574208 & -1.942094 & 1 & $-6.512132^{\star}$ & -3.465100 & -2.919800 \\
\hline LNCP & 1 & -2.381825 & -2.574171 & -1.942089 & 1 & -2.429654 & -3.465200 & -2.919600 \\
\hline$\triangle \mathrm{LNCP}$ & 1 & $-11.84818^{\star}$ & -2.574208 & -1.942094 & 1 & $-12.67868^{\star}$ & -3.465100 & -2.919800 \\
\hline LNCR & 1 & -2.160385 & -2.574171 & -1.942089 & 1 & -2.254017 & -3.465200 & -2.919600 \\
\hline$\triangle \mathrm{LNCR}$ & 1 & $-4.761738^{\star}$ & -2.574208 & -1.942094 & 1 & $-8.251913^{*}$ & -3.465100 & -2.919800 \\
\hline LNTBL & 1 & -1.718813 & -2.574171 & -1.942089 & 1 & -1.731301 & -3.465200 & -2.919600 \\
\hline$\triangle \mathrm{LNTBL}$ & 1 & $-8.068009^{*}$ & -2.574208 & -1.942094 & 1 & $-9.000464^{*}$ & -3.465100 & -2.919800 \\
\hline
\end{tabular}

Note: 1) $\Delta$ Represents first difference of the respective variables. 2) ${ }^{\star}$ Indicates rejection of $\mathrm{H}_{0}$ at the one per cent level of significance $3{ }^{* \star}$ Indicates rejection of $\mathrm{H}_{0}$ at the five per cent level of significance. 
(c)

Observed Test Statistics

\begin{tabular}{|c|c|c|c|c|c|c|c|c|c|c|}
\hline \multirow{2}{*}{ Variables } & \multicolumn{5}{|c|}{ With Constant } & \multicolumn{5}{|c|}{ With Constant and Trend } \\
\hline & $\mathrm{Lag}^{\circledR}$ & $\mathrm{MZa}$ & MZt & MSB & MPT & $\mathrm{Lag}^{\oplus}$ & $\mathrm{MZa}$ & $\mathrm{MZt}$ & MSB & MPT \\
\hline LNSX & 1 & -1.22073 & -0.49436 & 0.40497 & 12.2168 & 1 & -4.84922 & -1.48297 & 0.30582 & 18.3874 \\
\hline$\Delta$ LNSX & 1 & $-10.5983^{\star *}$ & $-2.22658^{\star \star}$ & $0.21009^{\star *}$ & $2.61201^{\star *}$ & 1 & $-35.9486^{*}$ & $-4.23594^{\star}$ & $0.11783^{*}$ & $2.55548^{*}$ \\
\hline LNCD & 1 & -5.78674 & -1.69104 & 0.29223 & 4.26576 & 1 & -5.82613 & -1.68859 & 0.28983 & 15.6154 \\
\hline$\triangle \mathrm{LNCD}$ & 1 & $-21.2568^{\star}$ & $-3.23196^{*}$ & $0.15204^{*}$ & $1.25269^{*}$ & 1 & $-50.6029^{\star}$ & $-5.02377^{\star}$ & $0.09928^{*}$ & $1.83237^{\star}$ \\
\hline LNCP & 1 & -11.3438 & -2.36717 & 0.20868 & 2.21781 & 1 & -11.6657 & -2.41224 & 0.20678 & 7.82724 \\
\hline$\triangle \mathrm{LNCP}$ & 1 & $-132.772^{*}$ & $-8.14773^{*}$ & $0.06137^{\star}$ & $0.18456^{*}$ & 1 & $-145.161^{*}$ & $-8.51799^{*}$ & $0.05868^{*}$ & $0.63238^{*}$ \\
\hline LNCR & 1 & -8.93614 & -2.11369 & 0.23653 & 2.74204 & 1 & -9.75011 & -2.19754 & 0.22539 & 9.39400 \\
\hline$\triangle \mathrm{LNCR}$ & 1 & $-31.2828^{*}$ & $-3.93841^{\star}$ & $0.12590^{*}$ & $0.83473^{*}$ & 1 & $-62.6749^{\star}$ & $-5.59369^{\star}$ & $0.08925^{\star}$ & $1.47384^{*}$ \\
\hline LNTBL & 1 & -5.95007 & -1.72226 & 0.28945 & 4.12611 & 1 & -6.02085 & -1.73220 & 0.28770 & 15.1326 \\
\hline$\Delta \mathrm{LNTBL}$ & 1 & $-87.6086^{*}$ & $-6.61820^{*}$ & $0.07554^{*}$ & $0.28022^{\star}$ & 1 & $-102.730^{*}$ & $-7.16100^{*}$ & $0.06971^{\star}$ & $0.90951^{*}$ \\
\hline
\end{tabular}

Critical Values ${ }^{\wedge}$

\begin{tabular}{rcccccccc}
\hline & \multicolumn{3}{c}{ With Constant } & \multicolumn{4}{c}{ With Constant and Trend } \\
\cline { 2 - 9 } Level & MZa & MZt & MSB & MPT & MZa & MZt & MSB & MPT \\
\hline $1 \%$ & -13.8000 & -2.58000 & 0.17400 & 1.78000 & -23.8000 & -3.42000 & 0.14300 & 4.03000 \\
$5 \%$ & -8.10000 & -1.98000 & 0.23300 & 3.17000 & -17.3000 & -2.91000 & 0.16800 & 5.48000 \\
$10 \%$ & -5.70000 & -1.62000 & 0.27500 & 4.45000 & -14.2000 & -2.62000 & 0.18500 & 6.67000 \\
\hline
\end{tabular}

Note: 1) $\Delta$ Represents first difference of the respective variable; 2) @ Indicates Spectral GLS-detrended AR based on SIC; 3) ^critical values are provided by Ng and Perron, 2001 (Table 1); 4) ${ }^{\star}$ Rejects the Null at one cent level of significance; 5$)^{*}$ Rejects the Null atfive cent level of significance.

analysis considering the series under the study are integrated of order one at log-level.

Next, the number of significant cointegrating vectors and the deterministic term are determined simultaneously by using maximum likelihood based $\lambda_{\max }$ and $\lambda_{\text {trace }}$ statistics suggested by Johansen $(1991,1995)$ and Johansen and Juselius (1990, 1994).

According to Engle and Granger (1987) under some regulatory conditions one can write a cointegrated process $y_{t}$ as a Vector error Correction Model:

$$
\Delta y_{t}=\mu_{o}+\Gamma_{1} \Delta y_{t-1}+\Gamma_{2} \Delta y_{t-2}+\cdots+\Gamma_{p-1} \Delta y_{t-(p-1)}+\Pi y_{t-1}+\varepsilon_{t}
$$

where $\Delta$ is a first difference notation, $\mu_{o}$ includes (non-seasonal) deterministic components, $y_{t}$ is a $p \times 1$ vector ( $p=5$ for this study), $\Gamma$ and $\Pi$ are coefficient-matrices that represents short and long-term impacts, respectively and $\varepsilon_{t}$ is residual vector assumed to be independent and identically distributed as multi-normal distribution with mean zero and variance $\Omega$. The Johansen procedure simply decomposes $\Pi$ in to two matrices $\alpha$ and $\beta$, both of which are $p \times r$ matrices $(r<p)$ such that $\Pi=\alpha \beta$. Thus, the rows of $\beta$ may be defined as the $r$ dis- 
tinct cointegrating vectors. Then a valid cointegrating vector will be given by the corresponding eigenvalue (Johansen, 1995). Here, $\alpha$ and $\beta$ are pxr matrices and denote respectively the loading and the cointegrating space with order $r$.

Johansen proposes a "Trace test" for determining the cointegrating rank " $r$ " such that:

$$
\hat{\lambda}_{\text {trace }}=-T \sum_{i=r+1}^{k} \ln \left(1-\lambda_{i}\right)
$$

and also proposes another likelihood ratio test to assess whether there is a maximum number of cointegrating vectors against $r+1$ such that:

$$
\hat{\lambda}_{\max }(r, r+1)=-T \ln \left(1-\lambda_{i}\right)
$$

with critical values given in Osterwald-Lenum (1992) and in Johansen (1995).

A systematic test is performed to determine the cointegrating rank and the form of the deterministic component in the cointegrating space. The optimum lag order used in the estimate is obtained on the basis of the information criteria like: Akaike Information Criterion (AIC) (Akaike, 1974), Schwarz Information Criterion (BIC) (Schwarz, 1978), and Hannan-Quinn Information Criterion (HQC) (Hannan \& Quinn, 1979), in a VAR framework. Here, we have obtained one lag order under BIC and $\mathrm{HQC}$ and 15 in AIC as the optimum one (see Table 2). Bearing in mind the informational efficiency of financial markets,

Table 2. Test for optimum lag order (Variables: LNCR, LNTBL, LNCP, LNCD).

\begin{tabular}{cccc}
\hline Lags & AIC & BIC & HQC \\
\hline 1 & -3.883732 & $-3.808992^{*}$ & $-3.853583^{*}$ \\
2 & -3.875648 & -3.785959 & -3.839469 \\
3 & -3.892541 & -3.787904 & -3.850332 \\
4 & -3.885845 & -3.766260 & -3.837607 \\
5 & -3.877789 & -3.743256 & -3.823521 \\
6 & -3.873528 & -3.724047 & -3.813230 \\
7 & -3.864833 & -3.700403 & -3.798505 \\
8 & -3.890649 & -3.711271 & -3.818291 \\
9 & -3.882470 & -3.688143 & -3.804082 \\
10 & -3.874976 & -3.665702 & -3.790559 \\
11 & -3.877955 & -3.653733 & -3.787508 \\
12 & -3.871897 & -3.632727 & -3.775421 \\
13 & -3.867915 & -3.613796 & -3.765408 \\
14 & -3.880369 & -3.611302 & -3.771833 \\
15 & $-3.895974^{*}$ & -3.611958 & -3.781408 \\
16 & -3.891152 & -3.592189 & -3.770557 \\
\hline & & & \\
\hline & & &
\end{tabular}

Note: 1 ) ${ }^{*}$ Indicate the best (that is, minimized) values of the respective information criteria, AIC = Akaike information criterion, BIC = Schwartz Bayesian information criterion and HQC = Hannan-Quinn information criterion; 2) VAR Lag Order: $\mathrm{AIC}=15, \mathrm{BIC}=1, \mathrm{HQC}=1$. 
empirical studies generally prefer lower-order lags (Schollhammer \& Sand, 1985; Eun \& Shim, 1989; Hassan \& Naka, 1996). Thus, we have used lower-order lag length, i.e., one throughout our subsequent empirical analyses. We have reported (see Table 3 ) the results of only the trace tests for cointegrating rank and the form of the deterministic component since $\lambda_{\text {trace }}$ statistic takes into account all $(n-r)$ of the smallest eigenvalues and tends to have more power than the $\lambda_{\max }$ statistic (see Kasa, 1992; Serlatis \& King, 1997; Wongbangpo \& Sharma, 2002). Moreover, in cases where a conflict between these two test statistics occurs, Johansen and Juselius (1990) emphasize the use of $\lambda_{\text {trace }}$ statistic.

We have relied on three models to ascertain the deterministic component present in the cointegrating space of the variables. The models are: 1) Model-1, where there is no data trend at level, and intercept with no trend is present in the cointegrating space of the variables; 2) Model-2, where there is a linear trend at log level, and intercept with no trend is present in the cointegrating space of the variables, and 3) Model-3, where there is a linear trend at level, and intercept with trend is present in the cointegrating space of the variables. The search procedure runs from the most restrictive model to the least one.

In the cointegrating relationships, we observed that the form of the deterministic component falls under both the Model-1 and Model-2. Following the economic intuition (Chen et al., 1986; Gujarati \& Porter, 2009) we have accepted the Model-2 where there is a linear trend at level, and intercept with no trend is present in the cointegrating space of the variables ${ }^{1}$. The study has found at most three cointegrating rank at the 0.05 level of significance which indicates the presence of a strong long-run relationship amongst the variables under the study.

Johansen and Juselius $(1990,1994)$ noted that the first cointegrating vector corresponding to the highest eigen value is most correlated with the stationarity part of the model. We have followed this to report the coefficient of the cointegrating vector. After normalizing the variable for stock market to one, the

Table 3. Deterministic Component in the Cointegrating Relationship.

\begin{tabular}{ccccccccccc}
\hline & \multicolumn{3}{c}{ Model-1 } & \multicolumn{3}{c}{ Model-2 } & \multicolumn{3}{c}{ Model-3 } \\
\cline { 2 - 6 } Null(Alt) & Eigenvalue & $\begin{array}{c}\text { Trace } \\
\text { Statistic }\end{array}$ & $\begin{array}{c}5 \% \text { Critical } \\
\text { Value }\end{array}$ & Eigenvalue & $\begin{array}{c}\text { Trace } \\
\text { Statistic }\end{array}$ & $\begin{array}{c}5 \% \text { Critical } \\
\text { Value }\end{array}$ & $\begin{array}{c}\text { Eigenvalue } \\
\text { Trace }\end{array}$ & $\begin{array}{c}\text { Tra Critical } \\
\text { Statistic }\end{array}$ & Value \\
\hline$r=0$ & 0.344280 & $226.6565^{*}$ & 76.97277 & 0.343899 & $225.5307^{*}$ & 69.81889 & 0.349888 & $256.9177^{*}$ & 88.80380 \\
$r \leq 1(r>1)$ & 0.230203 & $120.3071^{*}$ & 54.07904 & 0.229978 & $119.3277^{*}$ & 47.85613 & 0.231900 & $148.4039^{*}$ & 63.87610 \\
$r \leq 2(r>2)$ & 0.156440 & $54.37659^{*}$ & 35.19275 & 0.156270 & $53.47104^{*}$ & 29.79707 & 0.158628 & $81.91727^{*}$ & 42.91525 \\
$r \leq 3(r>3)$ & 0.034451 & 11.50519 & 20.26184 & 0.033778 & 10.65063 & 15.49471 & 0.111668 & $38.39143^{*}$ & 25.87211 \\
$r \leq 4(r>4)$ & 0.010541 & 2.670534 & 9.164546 & 0.007871 & 1.991434 & 3.841466 & 0.033368 & 8.552291 & 12.51798 \\
\hline
\end{tabular}

Note: 1) Model-1 represents "No deterministic trend with restricted constant", Model-2 represents "Linear deterministic trend with restricted constant" and Model-3 represents "Linear deterministic trend (restricted)" 2 ) *denotes rejection of the null hypothesis at $5 \%$ level.

${ }^{1}$ We have tested all issues under integration considering the Model 1 and found no substantial difference with results of the analysis considering Model 2. Moreover prediction is beyond the objective and scope of this paper 


$\begin{array}{ccllll} & \mathrm{SX}-0.003940, & \mathrm{CD}-0.001066, & \mathrm{CP}-0.015576, & \mathrm{CR}-0.030022, & \mathrm{TBL}-0.001399 \\ \text { SE: } & 0.00135 & 0.00212 & 0.00308 & 0.00319 & 0.00162 \\ \text { t-statistics: } & -2.92906 & -0.50187 & -5.05213 & -9.42159 & -0.86270\end{array}$

long-term relationship along with the short term dynamics corresponding to the highest eigen value and at the optimum lag orders with one cointegrating rank is:

LNSX $=$ 9.8422LNCD -10.467LNCP -19.149LNCR + 20.144LNTBL + 8.2697C

$\begin{array}{lllll}\text { SE : } & 3.15967 & 2.07939 & 2.29430 & 2.79503 \\ \text { t-statistics : }-3.11495 & 5.03378 & 8.34659 & -7.20734\end{array}$

The Portmanteau Test statistics, $\mathrm{Q}$ stat $=59.17999$ with $\mathrm{p}=0.0763$ and Adj $\mathrm{Q}$ stat $=59.60310$ with $\mathrm{p}=0.0712$, suggests the presence of no auto-correlation in the residuals of the above relation up to lag order two.

The cointegration and Portmanteau test results suggest a stable and significant long-term equilibrium relationship amongst the variables under the study. However, the adjustment process indicates more efficiency of the Indian call market than the other markets to return to equilibrium followed by $\mathrm{CP}$ and stock markets.

As suggested by Johansen (1991), LR-test is carried on to find the significance of the markets in the cointergation equation. The LR-statistics for stock, treasury bills, call rate, commercial paper, and certificate of deposit markets are $08.327295,20.1145,27.02052,11.81417$, and 4.558892 with probabilities 0.004 , $0.000,0.000,0.000$ and 0.0327 , respectively. The results suggest the strong presence of the market segments in the cointegrating space with the stock market.

According to the economic and finance theories, the signs of the variables are expected save the treasury bills market. In India, possibly, the positive relation between the markets may be due to the outcome of the rigidity of the markets (see Table 6). Many scholars found the positive relation between stock market and treasury bills market due mostly to the liquidity condition of the markets and economy, and the alternative reference rate floated and preferred by the economic units including the investors (Duca, 2007; Wongbangpo \& Sharma, 2002 (Indonesia, Malaysia); Goyenko \& Ukhov, 2009; Al-Naif, 2017 (Jordon and Oman); Jena et al. (2004) (India); Subburayan \& Srinivasan, 2014 (India)).

\subsection{The Causal Relationship}

Following Granger (1986), we have estimated the causal relationship between the variables within the framework of vector error correction model using the optimum lag order and the deterministic component. The results are presented in the Table 4.

We found unidirectional causality runs from $\mathrm{CR}, \mathrm{CD}$ and $\mathrm{CP}$ markets to stock market and bi-directional between TBL and SX. In sum, the results grossly attest that monetary policy announcement causes the Indian equity market to react within a period of a fortnight. 
Table 4. Causal-relationship of the Indian Stock Market and Select Segments of Money Market.

\begin{tabular}{cccccc}
\hline Null Hypothesis $\left(\mathrm{H}_{0}\right)$ & F-Statistic & p-value & Casualty runs from & Remarks \\
\hline LNCD does not Granger Cause LNSX & 5.35622 & 0.0215 & LNCD to LNSX & Unidirectional \\
LNSX does not Granger Cause LNCD & 1.19271 & 0.2758 & No Causality & \\
LNCP does not Granger Cause LNSX & 8.19958 & 0.0045 & LNCP to LNSX & Unidirectional \\
LNSX does not Granger Cause LNCP & 1.15821 & 0.2829 & No Causality & \\
LNCR does not Granger Cause LNSX & 7.94510 & 0.0052 & LNCR to LNSX & Unidirectional \\
LNSX does not Granger Cause LNCR & 1.99417 & 0.1591 & No Causality & \\
LNTBL does not Granger Cause LNSX & 5.61418 & 0.0186 & LNTBL to LNSX & Bidirectional \\
LNSX does not Granger Cause LNTBL & 5.75489 & 0.0172 & LNSX to LNTBL & \\
\hline
\end{tabular}

\subsection{The Response Accounting}

The empirical inferences based on the Granger causality test help only to qualify the flow of influences but the estimates of the Impulse Response Analysis can give us a quantitative idea about the impacts for several periods in future. If we assume that the equation system of a time series $y_{t}$ is stable, then the equilibrium is found by obtaining the final form of the system. By using lag operator and stability condition, we can write the form as:

$$
y_{t}=\hat{y}+v_{t}+\Gamma v_{t-1}+\Gamma^{2} v_{t}+\cdots
$$

where $v_{t}$ is the error term. From the equation (Equation (5)), we can say, $y_{t}$ would reach its equilibrium position $\hat{y}$, if $V_{t}, V_{t-1}, v_{t-2}$ equals to zero i.e., $v=0$. Now, if we inject a shock to the system by changing one of the $v^{2}$ in the above equation, for one period, and then returning it to zero thereafter, then we will see $y_{m t}$ will move away from, then return to its equilibrium. The impulse response of the system is the path whereby the variablem (i.e., $y_{m t}$ ) returns to the equilibrium position (see Greene, 2006).

Response to the innovation is likely to be sensitive to the ordering of the variables under the study. Following the suggestion of Lütkepohl and Reimers (1992) the variables are arranged as follows: Stock market is placed first since it is the primary variable of the study, next the $\mathrm{CD}, \mathrm{CP}, \mathrm{CR}$ and TBL market.

The results of the Impulse Response Analysis for a horizon of 10 fortnights to a "one standard deviation" shock are shown in Table 5. Here, one cointegrating rank is used in the VECM for the impulse-response analysis to investigate the robustness of causal results.

The Indian asset prices are observed to be sensitive more to their own innovations. The impacts of the "one standard deviation shock" in stock prices to the market itself are almost flat over the horizon of five months. A close scrutiny of the responses indicates that the market has the potentiality to be more efficient in the future. Strictly, the next best impact of the money market segments to the Indian stock market is the CR and CP followed by the CD and TBL. Similar 
Table 5. Impulse response analysis.

Response of LNSX to one standard deviation shock in the variables

\begin{tabular}{|c|c|c|c|c|c|}
\hline Period & LNSX & LNCD & LNCP & LNCR & LNTBL \\
\hline 1 & 0.038740 & 0.000000 & 0.000000 & 0.000000 & 0.000000 \\
\hline 2 & 0.045577 & -0.000283 & -0.002346 & -0.004795 & 0.002053 \\
\hline 3 & 0.041923 & 0.001651 & -0.008022 & -0.012211 & 0.000466 \\
\hline 4 & 0.042985 & 0.004524 & -0.011740 & -0.009986 & -0.001372 \\
\hline 5 & 0.044704 & 0.003680 & -0.010265 & -0.009826 & -0.001334 \\
\hline 6 & 0.044805 & 0.003366 & -0.009311 & -0.009874 & -0.001479 \\
\hline 7 & 0.044324 & 0.003506 & -0.009632 & -0.009943 & -0.001789 \\
\hline 8 & 0.044176 & 0.003459 & -0.009561 & -0.009864 & -0.001881 \\
\hline 9 & 0.044247 & 0.003460 & -0.009404 & -0.009700 & -0.001963 \\
\hline 10 & 0.044230 & 0.003367 & -0.009256 & -0.009671 & -0.001986 \\
\hline \multicolumn{6}{|c|}{ Response of LNCD to one standard deviation shock in the variables } \\
\hline Period & LNSX & LNCD & LNCP & LNCR & LNTBL \\
\hline 1 & 0.000000 & 0.059347 & 0.000000 & 0.000000 & 0.000000 \\
\hline 2 & -0.001790 & 0.029125 & 0.013934 & 0.001862 & 0.022740 \\
\hline 3 & -0.015307 & 0.035862 & 0.002149 & -0.000561 & 0.032722 \\
\hline 4 & -0.013607 & 0.036044 & -0.002364 & -0.003993 & 0.035112 \\
\hline 5 & -0.009224 & 0.037862 & -0.005322 & -0.002550 & 0.038304 \\
\hline 6 & -0.008003 & 0.037900 & -0.007211 & -0.006608 & 0.040804 \\
\hline 7 & -0.007419 & 0.039181 & -0.010013 & -0.007271 & 0.041759 \\
\hline 8 & -0.006711 & 0.039759 & -0.011690 & -0.008075 & 0.042416 \\
\hline 9 & -0.006057 & 0.039946 & -0.012222 & -0.008505 & 0.042912 \\
\hline 10 & -0.005718 & 0.040226 & -0.012813 & -0.008787 & 0.043129 \\
\hline
\end{tabular}

Response of LNCP to one standard deviation shock in the variables

\begin{tabular}{cccccc}
\hline Period & LNSX & LNCD & LNCP & LNCR & LNTBL \\
\hline 1 & 0.000000 & 0.000000 & 0.086899 & 0.000000 & 0.000000 \\
2 & -0.012822 & 0.013192 & 0.054326 & -0.007820 & 0.016263 \\
3 & -0.026602 & 0.007993 & 0.041731 & -0.020869 & 0.037774 \\
4 & -0.020149 & 0.016306 & 0.031576 & -0.015936 & 0.041077 \\
5 & -0.013675 & 0.013589 & 0.030859 & -0.018547 & 0.046100 \\
6 & -0.012903 & 0.015480 & 0.026949 & -0.023467 & 0.049357 \\
7 & -0.011953 & 0.017699 & 0.021853 & -0.025091 & 0.050491 \\
8 & -0.010598 & 0.018175 & 0.020008 & -0.025811 & 0.051700 \\
9 & -0.009634 & 0.018596 & 0.019154 & -0.026542 & 0.052330 \\
10 & -0.009213 & 0.018874 & 0.018353 & -0.026995 & 0.052669 \\
\hline
\end{tabular}


Response of LNCR to one standard deviation shock in the variables

\begin{tabular}{|c|c|c|c|c|c|}
\hline Period & LNSX & LNCD & LNCP & LNCR & LNTBL \\
\hline 1 & 0.000000 & 0.000000 & 0.000000 & 0.092956 & 0.000000 \\
\hline 2 & -0.018549 & -0.018525 & 0.015066 & 0.013053 & 0.032924 \\
\hline 3 & -0.011656 & 0.009333 & -0.019575 & 0.028300 & 0.038465 \\
\hline 4 & -0.005440 & 0.005529 & -0.031135 & 0.021992 & 0.049257 \\
\hline 5 & -0.001941 & 0.005396 & -0.031109 & 0.015982 & 0.055558 \\
\hline 6 & 0.001259 & 0.010627 & -0.040005 & 0.014507 & 0.056264 \\
\hline 7 & 0.002605 & 0.009992 & -0.042488 & 0.011484 & 0.059079 \\
\hline 8 & 0.003860 & 0.011868 & -0.045089 & 0.010504 & 0.059892 \\
\hline 9 & 0.004903 & 0.012072 & -0.046357 & 0.009940 & 0.060491 \\
\hline 10 & 0.005286 & 0.012337 & -0.047047 & 0.009335 & 0.060977 \\
\hline \multicolumn{6}{|c|}{ Response of LNTBL to one standard deviation shock in the variables } \\
\hline Period & LNSX & LNCD & LNCP & LNCR & LNTBL \\
\hline 1 & 0.000000 & 0.000000 & 0.000000 & 0.000000 & 0.046497 \\
\hline 2 & -0.002107 & -0.005347 & -0.001875 & 0.001331 & 0.055221 \\
\hline 3 & -0.003385 & -0.007086 & -0.005823 & 0.002852 & 0.058466 \\
\hline 4 & -0.002106 & -0.004126 & -0.010410 & -0.004216 & 0.061508 \\
\hline 5 & 0.000984 & -0.001924 & -0.014687 & -0.004543 & 0.063546 \\
\hline 6 & 0.002205 & -0.001637 & -0.016887 & -0.006013 & 0.065304 \\
\hline 7 & 0.002799 & -0.001178 & -0.018147 & -0.007112 & 0.066083 \\
\hline 8 & 0.003395 & -0.000555 & -0.019416 & -0.007476 & 0.066399 \\
\hline 9 & 0.003773 & -0.000453 & -0.019910 & -0.007904 & 0.066767 \\
\hline 10 & 0.004000 & -0.000251 & -0.020297 & -0.008097 & 0.066927 \\
\hline
\end{tabular}

results are obtained in TBL market where after the market itself the next best impact from money market segments are $\mathrm{CP}, \mathrm{CR}$ in increasing trend, stock market in decreasing first then in increasing trend and the impacts of the $\mathrm{CD}$ market is marginal. The response of $\mathrm{CD}, \mathrm{CP}$ and $\mathrm{CR}$ are more by the impulses from TBL market. It grossly confirms the results obtained from Granger causality test which runs from the segments of money market to stock prices.

For the sake of further clarity of the intra and inter structural relationship among the markets under our study, we propose to pursue variance decomposition analysis.

Findings of the forecast error variance decomposition test corroborate the observations obtained in impulse response analysis. In a bank dominated economy like India, variances in stock and treasury bills market are expectedly explained largely by themselves (93) and (94.5) percent, respectively for the next 10 fortnights. While analyzing the forecast error variance of stock market, money market activities seem to be indifferent in developing the stock market in In- 
dia and the role of monetary policy is inadequate or marginal in this respect. The Indian call and commercial paper markets are highly flexible markets followed by CD market. The role of treasury bills market to explain all the other markets under this study is very high for the future period of five months considered by this research (see Table 6).

Table 6. Variance decomposition analysis.

\begin{tabular}{|c|c|c|c|c|c|c|}
\hline \multicolumn{7}{|c|}{ Variance Decomposition of LNSX } \\
\hline Period & S.E. & LNSX & LNCD & LNCP & LNCR & LNTBL \\
\hline 1 & 0.039427 & 100.0000 & 0.000000 & 0.000000 & 0.000000 & 0.000000 \\
\hline 2 & 0.060284 & 99.39510 & 0.129523 & 0.296915 & 0.145314 & 0.033151 \\
\hline 3 & 0.077585 & 97.69469 & 0.120746 & 1.061516 & 0.928492 & 0.194557 \\
\hline 4 & 0.092829 & 96.33952 & 0.108251 & 1.734572 & 1.402503 & 0.415155 \\
\hline 5 & 0.106356 & 95.33543 & 0.103872 & 2.177299 & 1.767084 & 0.616312 \\
\hline 6 & 0.118584 & 94.59060 & 0.098467 & 2.522494 & 2.021333 & 0.767107 \\
\hline 7 & 0.129763 & 94.03766 & 0.095474 & 2.767164 & 2.212901 & 0.886797 \\
\hline 8 & 0.140107 & 93.61724 & 0.092740 & 2.957296 & 2.355227 & 0.977495 \\
\hline 9 & 0.149759 & 93.29153 & 0.090861 & 3.101889 & 2.466309 & 1.049408 \\
\hline 10 & 0.158838 & 93.03326 & 0.089257 & 3.217623 & 2.553611 & 1.106249 \\
\hline \multicolumn{7}{|c|}{ Variance Decomposition of LNCD } \\
\hline Period & S.E. & LNSX & LNCD & LNCP & LNCR & LNTBL \\
\hline 1 & 0.062280 & 0.136015 & 99.86398 & 0.000000 & 0.000000 & 0.000000 \\
\hline 2 & 0.084046 & 0.612720 & 87.68602 & 2.720305 & 0.494873 & 8.486083 \\
\hline 3 & 0.103430 & 0.754530 & 85.41155 & 1.853872 & 0.337039 & 11.64301 \\
\hline 4 & 0.119948 & 0.722204 & 82.74772 & 1.443425 & 0.282990 & 14.80366 \\
\hline 5 & 0.134765 & 0.663008 & 81.22382 & 1.150932 & 0.260730 & 16.70151 \\
\hline 6 & 0.148152 & 0.614617 & 80.01050 & 0.959477 & 0.262307 & 18.15310 \\
\hline 7 & 0.160503 & 0.573320 & 79.16631 & 0.819407 & 0.264607 & 19.17635 \\
\hline 8 & 0.171975 & 0.541137 & 78.49339 & 0.715706 & 0.270288 & 19.97948 \\
\hline 9 & 0.182748 & 0.514886 & 77.97965 & 0.634894 & 0.274717 & 20.59586 \\
\hline 10 & 0.192921 & 0.493765 & 77.56038 & 0.570769 & 0.279184 & 21.09590 \\
\hline \multicolumn{7}{|c|}{ Variance Decomposition of LNCP } \\
\hline Period & S.E. & LNSX & LNCD & LNCP & LNCR & LNTBL \\
\hline 1 & 0.090370 & 1.225180 & 17.92320 & 80.85162 & 0.000000 & 0.000000 \\
\hline 2 & 0.118032 & 3.554774 & 24.24583 & 69.30125 & 0.203506 & 2.694642 \\
\hline 3 & 0.142172 & 3.994902 & 25.64101 & 60.15242 & 2.376870 & 7.834790 \\
\hline 4 & 0.161484 & 3.775522 & 27.69354 & 53.27336 & 3.548987 & 11.70859 \\
\hline 5 & 0.179619 & 3.517047 & 28.23835 & 48.61512 & 4.705865 & 14.92363 \\
\hline
\end{tabular}




\section{Continued}

\begin{tabular}{|c|c|c|c|c|c|c|}
\hline 6 & 0.195766 & 3.284479 & 28.95906 & 45.00381 & 5.532284 & 17.22037 \\
\hline 7 & 0.210940 & 3.093933 & 29.29070 & 42.34637 & 6.217557 & 19.05144 \\
\hline 8 & 0.225002 & 2.939140 & 29.62937 & 40.23803 & 6.741037 & 20.45242 \\
\hline 9 & 0.238309 & 2.813791 & 29.84552 & 38.58508 & 7.170243 & 21.58537 \\
\hline 10 & 0.250884 & 2.710754 & 30.04277 & 37.23249 & 7.515599 & 22.49839 \\
\hline \multicolumn{7}{|c|}{ Variance Decomposition of LNCR } \\
\hline Period & S.E. & LNSX & LNCD & LNCP & LNCR & LNTBL \\
\hline 1 & 0.093404 & 1.869840 & 1.317923 & 1.637449 & 95.17479 & 0.000000 \\
\hline 2 & 0.106194 & 8.660904 & 1.059621 & 2.213834 & 77.83937 & 10.22627 \\
\hline 3 & 0.121698 & 8.151647 & 2.887828 & 6.021089 & 64.63908 & 18.30035 \\
\hline 4 & 0.135630 & 7.585885 & 2.686021 & 6.117413 & 53.70466 & 29.90602 \\
\hline 5 & 0.149556 & 6.718304 & 3.060480 & 8.201467 & 45.76352 & 36.25623 \\
\hline 6 & 0.162462 & 6.078531 & 3.027233 & 8.972097 & 39.70466 & 42.21748 \\
\hline 7 & 0.174798 & 5.521576 & 3.128860 & 10.06746 & 35.16283 & 46.11928 \\
\hline 8 & 0.186348 & 5.095747 & 3.134460 & 10.70888 & 31.60949 & 49.45143 \\
\hline 9 & 0.197324 & 4.743249 & 3.171944 & 11.34761 & 28.80855 & 51.92865 \\
\hline 10 & 0.207724 & 4.460055 & 3.183476 & 11.80829 & 26.53213 & 54.01605 \\
\hline \multicolumn{7}{|c|}{ Variance Decomposition of LNTBL } \\
\hline Period & S.E. & LNSX & LNCD & LNCP & LNCR & LNTBL \\
\hline 1 & 0.047528 & 3.254437 & 3.257179 & 0.104657 & 1.049576 & 92.33415 \\
\hline 2 & 0.074795 & 3.417698 & 2.297726 & 0.074175 & 1.084418 & 93.12598 \\
\hline 3 & 0.095947 & 3.340668 & 2.125596 & 0.197774 & 0.800627 & 93.53534 \\
\hline 4 & 0.113857 & 3.167094 & 2.031810 & 0.308762 & 0.642965 & 93.84937 \\
\hline 5 & 0.129530 & 3.024454 & 1.972259 & 0.391018 & 0.540107 & 94.07216 \\
\hline 6 & 0.143591 & 2.914105 & 1.935019 & 0.455822 & 0.470308 & 94.22474 \\
\hline 7 & 0.156440 & 2.829936 & 1.907721 & 0.504192 & 0.420021 & 94.33813 \\
\hline 8 & 0.168329 & 2.764838 & 1.888017 & 0.542037 & 0.382592 & 94.42252 \\
\hline 9 & 0.179443 & 2.713730 & 1.872645 & 0.571526 & 0.353687 & 94.48841 \\
\hline 10 & 0.189912 & 2.672805 & 1.860631 & 0.595258 & 0.330822 & 94.54048 \\
\hline
\end{tabular}

In essence, the observations from the impulse response analysis and forecast error variance decomposition analysis suggest that money market and equity market are not the substitutes to each other and growing transmission of influence from one sector to the other is indicative of their complementary role in the Indian economy.

\section{Contribution, Gap and Scope of Further Study}

This study firstly and objectively showed that not only the yields from Treasury 
Bills market which is widely used in the finance literature, Call Money market rates can also be used to describe the equity market in India. It drastically reduces confusion of the researchers in using treasury-yields or call rates in empirical research in finance. The issue can be established firmly by more research considering different economies.

The results and observations of the study should be accepted with caution due to the inevitable bias and limitations of the econometric tools used. Theoretically, the relationship may well take the non-linear form which is not assessed by the study. Consideration of moderately low frequency data, not all the rates of the segments of the money market like, "repo rate", "narrow based equity index", etc., are some of the gaps of the study. Moreover, the reasons for cointegration or no cointegration is beyond the scope of the paper. The issues are left for further studies.

\section{Conclusion}

Advocates of free economy suggest the integration of financial markets "is a must" for better industrialization, development and finally the growth of an economy. Objective evaluation of the status and the causal direction of the markets would certainly help the policy planners to set the direction of the markets to achieve the desired growth. Relying on the robust statistical and econometric tools this paper attempts to investigate the relationship amongst stock and some select segments of Indian money market viz., Certificate of Deposit, Commercial Paper, Call Money, and Treasury Bills on the basis of the data at log-level covering a colourful period of the Indian economy. The results of Johansen and Juselius (1990) cointegration test suggest strong integration amongst the markets and statistically significant presence of all the markets in the cointegration space. All the markets are statistically significantly efficient to return to equilibrium except the Certificate of Deposit and Treasury Bills market. Granger causality expectedly runs from money to stock market and Forecast Error Variance Decomposition Analysis indicates the rigidity of the stock and treasury bills market only, hence, warrants more attention of the Indian policy planners to take adequate steps to converge these markets.

\section{Conflicts of Interest}

The authors declare no conflicts of interest regarding the publication of this paper.

\section{References}

Abdullah, D. A., \& Hayworth, S. C. (1993). Macroeconomics of Stock Price Fluctuations. Quarterly Journal of Business and Economics, 32, 50-67.

Acikalin, S., Aktas, R., \& Unal, S. (2008). Relationships between Stock Markets and Macroeconomic Variables: An Empirical Analysis of the Istanbul Stock Exchange. Investment Management and Financial Innovations, 5, 8-16.

Addo, A., \& Sunzuoye, F. (2013). Short Term Interest Rates Impact On Ghana Stock Market. European Journal of Business And Economics, 8, 15-24. 
https://doi.org/10.12955/ejbe.v8i3.391

Agarwal, P. (2004). Interest Rate and Investment in East Asia: An Empirical Evaluation of Various Financial Liberalisation Hypotheses. The Journal of Development Studies, 40, 142-173. https://doi.org/10.1080/0022038042000213238

Akaike, H. (1974). A New Look at the Statistical Model Identification. IEEE Transactions on Automatic Control, 19, 716-723. https://doi.org/10.1109/TAC.1974.1100705

Al-Naif, K. L. (2017). The Relationship between Interest Rates and Stock Market Index: Empirical Evidence from Arabian Countries. Research Journal of Finance and Accounting, 8, 181-191.

AL-Sharkas, A. (2004). The Dynamic Relationship between Macroeconomic Factors and the Jordanian Stock Market. International Journal of Applied Econometrics and Quantitative Studies, 1, 97-114.

Bernanke, B. S., \& Kuttner, K. N. (2004) What Explains the Stock Market's Reaction to Federal Reserve Policy? Finance and Economics Discussion Series 2004-16, Cambridge, MA: National Bureau of Economic Research. https://doi.org/10.3386/w10402

Bernanke, B., \& Gertler, M. (1989). Agency Costs, Net Worth and Business Fluctuations. American Economic Review, 79, 14-31.

Bhoi, B. K., \& Dhall, S. C. (1998). Integration of Financial Markets in India: An Empirical Evaluation. RBI Occasional Papers, 19, 345-380.

Chen, N. F., Roll, R., \& Ross, S. A. (1986). Economic Forces and the Stock Market. Journal of Business, 59, 383-403. https://doi.org/10.1086/296344

Clark, T. E., \& Kozicki, S. (2005). Estimating Equilibrium Real Interest Rates in RealTime. The North American Journal of Economics and Finance, 16, 395-413. https://doi.org/10.1016/j.najef.2005.04.002

Dimitrova, D. (2005). The Relationship between Exchange Rates and Stock Prices: Studied in a Multivariate Model. Issues in Political Economy, 14, 1-25.

http://www.elon.edu/e-web/students/ipe/default.xhtml

Duca, G. (2007). The Relationship between the Stock Market and the Economy: Experience from International Financial Markets. Bank of Valletta Review, 36, 1-12.

Ehrmann, M., Fratzscher, M., \& Rigobon, R. (2009). Stocks, Bonds, Money Markets and Exchange Rates: Measuring International Financial Transmission. Journal of Applied Econometrics, 26, 948-974. https://doi.org/10.1002/jae.1173

Elliott, G., Rothenberg, T. J., \& Stock, J. H. (1996). Efficient Test for an Autoregressive Unit Root. Econometrica, 64, 813-836. https://doi.org/10.2307/2171846

Engle, R. F., \& Granger, C. W. J. (1987). Co-Integration and Error Correction: Representation, Estimation and Testing. Econometrica, 55, 251-276.

https://doi.org/10.2307/1913236

Eun, C., \& Shim, S. (1989). International Transmission of Stock Market Movements. Journal of Financial and Quantitative Analysis, 24, 241-256. Finance, 44, 1115-1153. https://doi.org/10.2307/2330774

Fry, M. J. (1978). Money Capital or Financial Deepening in Economic Development. Journal of Money Credit and Banking, 10, 464-475. https://doi.org/10.2307/1991576

Galbraith, J. K. (1955). The Great Crash 1929. London: Penguin.

Goyenko, R. Y., \& Ukhov, A. D. (2009). Stock and Bond Market Liquidity: A Long-Run Empirical Analysis. Journal of Financial and Quantitative Analysis, 44, 189-212. https://doi.org/10.1017/S0022109009090097

Granger, C. W. J. (1986). Developments in the Study of Cointegrated Economic Variables. Oxford Bulletin of Economics and Statistics, 48, 213-228. 
https://doi.org/10.1111/j.1468-0084.1986.mp48003002.x

Greene, W. H. (2006). Econometric Analysis. New Delhi: Pearson.

Gujarati, D. N., \& Porter, D. C. (2009). Basic Econometrics. New York, NY: McGraw-Hill.

Hannan, E. J., \& Quinn, B. G. (1979). The Determination of the Order of an Autoregression. Journal of the Royal Statistical Society: Series-B, 41, 190-195. https://doi.org/10.1111/j.2517-6161.1979.tb01072.x

Hassan, M. K., \& Naka, A. (1996). Short-Run and Long-Run Dynamic Linkages among International Stock Markets. International Review of Economics \& Finance, 5, 387-405. https://doi.org/10.1016/S1059-0560(96)90025-8

Humpe, A., \& Macmillan, P. (2007). Can Macroeconomic Variables Explain Long Term Stock Market Movements? A Comparison of the US and Japan. CDMA Working Paper No. 07/20, St Andrews: Centre for Dynamic Macroeconomic Analysis. https://doi.org/10.2139/ssrn.1026219

Jena, P. R., Murty, K. N., \& Narasimhan, V. (2004). Integration of Financial Markets in India: An Empirical Analysis. 6th Annual Conference on Money and Finance, Mumbai.

Johansen, S. (1991). Estimation and Hypothesis Testing of Cointegration Vectors in Gaussian Vector Autoregressive Models. Econometrica, 59, 1551-1580. https://doi.org/10.2307/2938278

Johansen, S. (1995). Likelihood Based Inference in Cointegrated Vector Autoregressive Models. Oxford: Oxford University Press. Journal of Money Credit and Banking, 10.

Johansen, S., \& Juselius, K. (1990). Maximum Likelihood Estimation and Procedure for Inference on Cointegration-With Application to the Demand for Money. Oxford Bulletin of Economics and Statistics, 52, 169-210. https://doi.org/10.1111/j.1468-0084.1990.mp52002003.x

Johansen, S., \& Juselius, K. (1994). Identification of the Long-Run and the Short-Run Structure. An Application of the ISLM Model. Journal of Econometrics, 63, 7-36. https://doi.org/10.1016/0304-4076(93)01559-5

Kasa, K. (1992). Common Stochastic Trends in International Stock Markets. Journal of Monetary Economics, 29, 95-124. https://doi.org/10.1016/0304-3932(92)90025-W

Khrawish, H. A., Siam, W. Z., \& Jaradat, M. (2010). The Relationships between Stock Market Capitalization Rate and Interest Rate: Evidence from Jordan. Business and Economic Horizons, 2, 60-66. https://doi.org/10.15208/beh.2010.17

Kiyotaki, N., \& Moore, J. (1997). Credit Cycles. Journal of Political Economy, 105, 211 248. https://doi.org/10.1086/262072

Lütkepohl, H., \& Reimers, H. E. (1992). Impulse Response Analysis of Cointegrated Systems. Journal of Economic Dynamics and Control, 16, 53-78. https://doi.org/10.1016/0165-1889(92)90005-Y

McMillan, D. G. (2001). Cointegration Relationships between Stock Market Indices and Economic Activity: Evidence from US Data. Discussion Paper, St. Andrews: University of St. Andrews.

Modigliani, F. (1971). Monetary Policy and Consumption: Linkages via Interest Rate and Wealth Effects in the FMP Model. In F. Modigliani, J. Tobin, W. C. Dolde, P. J. Taubman, G. D. Green, D. I. Meiselman et al. (Eds.), Consumer Spending and Monetary Policy: The Linkages (pp. 9-84). Conferences Series, No. 5, Boston, MA: Federal Reserve Bank of Boston.

Nasseh, A., \& Strauss, J. (2000). Stock Prices and Domestic and International Macroeconomic Activity: A Cointegration Approach. Quarterly Review of Economics and Finance, 40, 229-245. https://doi.org/10.1016/S1062-9769(99)00054-X 
Ng, S., \& Perron, P. (2001). LAG Length Selection and the Construction of Unit Root Tests with Good Size and Power. Econometrica, 69, 1519-1554. https://doi.org/10.1111/1468-0262.00256

Osterwald-Lenum, M. (1992). A Note with Quantiles of the Asymptotic Distribution of the Maximum Likelihood Cointegration Rank Test Statistic. Oxford Bulletin of Economics and Statistics, 54, 461-472. https://doi.org/10.1111/j.1468-0084.1992.tb00013.x

Pallegedara, A. (2012). Dynamic Relationships between Stock Market Performance and Short Term Interest Rate Empirical Evidence from Sri Lanka. Munich Personal RePEc Archive, Paper No. 40773, 461-464. https://doi.org/10.2139/ssrn.2156150 http://atmpra.ub.uni-muenchen.de/40773/

Ray, H. (2007). Macroeconomic Variables and Stock Market Behaviour: An Indian Experience. Artha Vijnana, 49, 255-274. https://doi.org/10.1093/biomet/71.3.599

Ray, H. (2008). Dynamic Interactions of Exchange Rates, Stock Prices and Macroeconomic Variables in India. The ICFAI Journal of Applied Finance, 14, 19-33.

Ray, H., \& Sarkar, J. (2014). Macroeconomic Link to Indian Capital Market: A Post-Liberalization Evidence. Modern Economy, 5, 272-288.

https://doi.org/10.4236/me.2014.54028

Said, S., \& Dicky, D. A. (1984). Testing for Unit Roots in Autoregressive-Moving Average Models of Unknown Order. Biometrika, 71, 599-607.

https://doi.org/10.1093/biomet/71.3.599

Sanati, G. (2010). Macro Impact of Financial Integration: An Empirical Study of Pre and Post Liberalized India. Journal of Quantitative Economics, 11, 250-276.

Schollhammer, H., \& Sand, O. (1985). The Interdependence among the Stock Markets of Major European Countries and United States: An Empirical Investigation of Interrelationships among National Stock price Movements. International Management Review, $25,17-25$.

Schwarz, G. (1978). Estimating the Dimension of a Model. Annals of Statistics, 6, 461464. https://doi.org/10.1214/aos/1176344136

Schwert, G. W. (1989). Why Does Stock Market Volatility Change over Time? Journal of Finance, 44, 1115-1153. https://doi.org/10.1111/j.1540-6261.1989.tb02647.x

Serlatis, A., \& King, M. (1997). Common Stochastic Trends and Convergence of European Union Stock Markets. The Manchester School of Economics \& Social Studies, 65, 44-57. https://doi.org/10.1111/1467-9957.00042

Subburayan, B., \& Srinivasan,V. (2014). The Effects of Macroeconomic Variables on CNX Bankex Returns: Evidence from Indian Stock Market. International Journal of Management and Business studies, 4, 67-71.

Tobin, J. (1969). A General Equilibrium Approach to Monetary Theory. Journal of Money, Credit and Banking, 1, 15-29. https://doi.org/10.2307/1991374

White, H. (1910). The Stock Exchange and Money Market. The Annals of American Academy of Political and Social Science, 36, 85-95. https://doi.org/10.1177/000271621003600307

Wong, W. K., Khan, H., \& Du, J. (2005). Money, Interest Rate, and Stock Prices: New Evidence from Singapore and the United States. U21 Global Working Paper No. 007. http://ssrn.com/abstract $=1607605$ https://doi.org/10.2139/ssrn.1607605

Wongbangpo, P., \& Sharma, S. C. (2002). Stock Market and Macroeconomic Fundamental Dynamic Interactions: ASEAN-5 Countries. Journal of Asian Economics, 13, 27-51. https://doi.org/10.1016/S1049-0078(01)00111-7 